\title{
Endoscopic management of buried bumper syndrome using a novel grasping-type scissor forceps
}

With an incidence ranging between $0.3 \%$ and $2.4 \%$, buried bumper syndrome (BBS) is a relatively rare complication after percutaneous endoscopic gastrostomy (PEG) in which the internal fixation device of the cannula - the retention bumper - migrates partially (incomplete BBS) or completely (complete BBS) into the gastric wall with subsequent mucosal overgrowth [1,2]. Management of complete BBS can be challenging, and a variety of endoscopic devices have been described for endoscopic treatment, including needle-knives, wire-guided papillotomes, the sphincterotome-like Flamingo device, or a combination of different techniques [3-5].

The Clutch Cutter is a forceps-type resection device with a serrated cutting edge that allows simultaneous grasping and cutting or coagulating of tissue. The outer edge of the Clutch Cutter is insulated; electrosurgical current energy is concentrated at the closed blade to avoid unintentional incision. We present the first case of endoscopic removal of a complete BBS with the Clutch Cutter.

A 77-year-old man with a known radiation-induced esophageal stricture requiring intermittent enteral feeding through a PEG presented with obstruction of his PEG tube. Esophagogastroduodenoscopy showed a 4-cm area of granulomatous - fibrotic tissue with a central retraction in the anterior wall of the gastric antrum, thereby confirming complete BBS ( Fig. 1 a). A .035-inch Jagwire was inserted through the gastrostomy to identify the center of the retention bumper and was used as a guide for subsequent incisions. Next, granulomatous tissue was grasped with the opened Clutch Cutter and, with tissue inside the forceps, the Clutch Cutter was gently pulled back in order to avoid cutting too deep ( $\triangleright$ Video 1 ). During pull-back, electrocautery was applied using an Erbe Vio $200 \mathrm{D}$-system with the following settings: forced coagulation 30 W, Endo Cut Q with
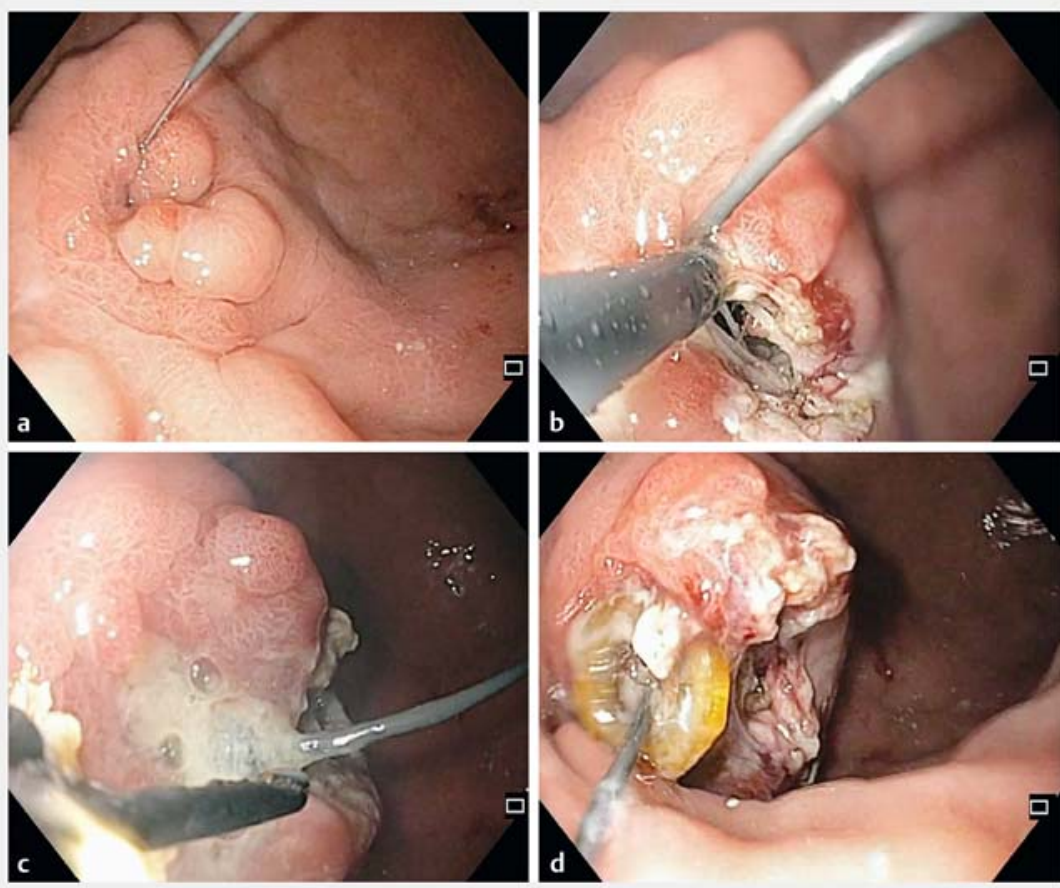

Fig. 1 Different steps of endoscopic management of a complete buried bumper with the Clutch Cutter. a Endoscopic appearance of complete buried bumper syndrome (BBS): the internal fixation device ("bumper") is completely overgrown by granulomatous and fibrotic mucosa. A .035-inch Jagwire was inserted to identify the center of the retention bumper and used as a guide for subsequent incisions. $\mathbf{b}, \mathbf{c}$ The granulomatous tissue overgrowing the retention bumper was radially cut at two sites on opposite sides of the Jagwire to create a slitlike mucosal pocket. d The external percutaneous endoscopic gastrostomy tube was mobilized and, while undergoing $360^{\circ}$ rotation, pushed through the incised mucosa into the gastric lumen.

effect 1 , duration 3, interval 1. The granulomatous tissue overgrowing the buried bumper was radially incised at two sites on opposite sides of the Jagwire, leading to the creation of a slit-like mucosal pocket ( $\mathbf{F i g . 1} \mathbf{1}$ b, c). The PEG tube was then mobilized and gently pushed towards the gastric lumen from externally, leading to release of the buried bumper and the PEG tube remnant from the overgrown tissue into the gastric lumen ( Fig.1d; $>$ Video 1). Total procedure time from insertion to withdrawal of the endoscope was 11 minutes, and the whole procedure was performed with the patient under conscious sedation with midazolam and with broad-spectrum antibiotic prophylaxis.

In conclusion, our case illustrates the potential of the Clutch Cutter for rapid and safe endoscopic treatment of BBS.

Endoscopy_UCTN_Code_CPL_1AH_2AI

\section{Competing interests}

The authors declare that they have no conflict of interest. 


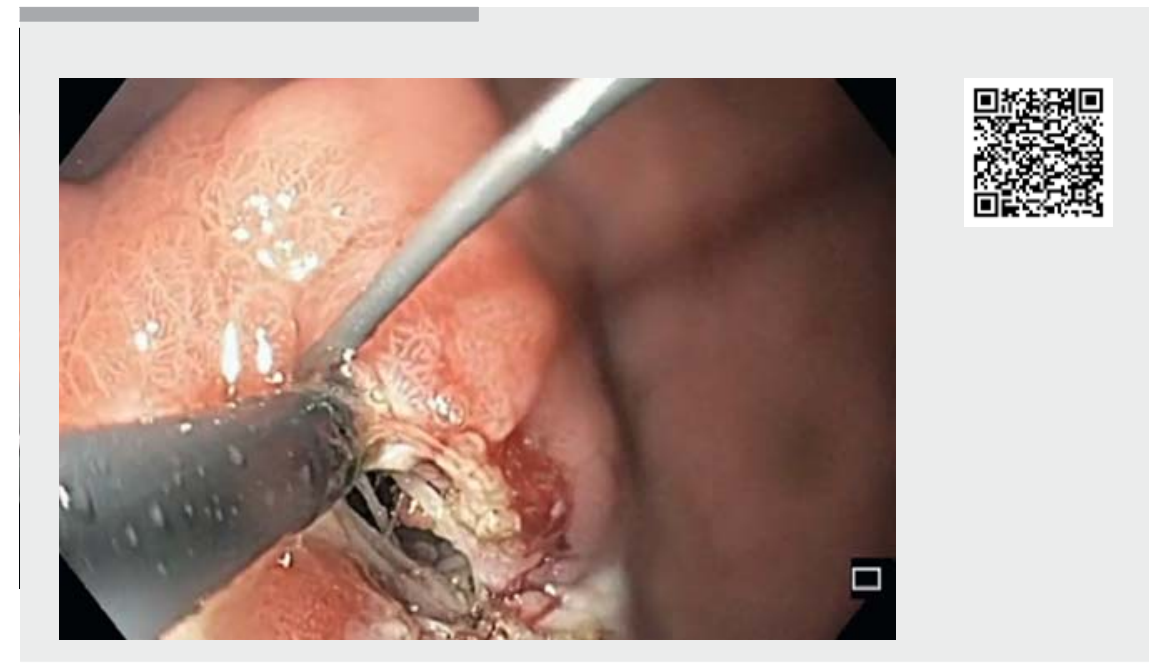

Video 1 Endoscopic removal of a completely buried bumper with the Clutch Cutter.

The authors

Timo Rath, Francesco Vitali, Andreas Nägel, Markus F. Neurath

Department of Medicine 1, Division of Gastroenterology, Ludwig Demling Endoscopy Center of Excellence, Erlangen University Hospital, Erlangen, Germany

\section{Corresponding author}

\section{Timo Rath, MD}

Ludwig Demling Endoscopy Center of Excellence, Division of Gastroenterology, Department of Medicine 1, Erlangen University Hospital, Ulmenweg 18 , 91054 Erlangen, Germany Fax: +49-9131-8535209

Timo.Rath@uk-erlangen.de

\section{Bibliography}

Endoscopy 2021; 53: E21-E22

DOI 10.1055/a-1173-7494

ISSN 0013-726X

published online 29.5.2020

(c) 2020. Thieme. All rights reserved.

Georg Thieme Verlag KG, Rüdigerstraße 14, 70469 Stuttgart, Germany

\section{ENDOSCOPY E-VIDEOS}

https:/|eref.thieme.de/e-videos

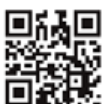

Endoscopy E-Videos is a free access online section, reporting on interesting cases and new

techniques in gastroenterological endoscopy. All papers include a high quality video and all contributions are freely accessible online.

This section has its own submission website at https://mc.manuscriptcentral.com/e-videos
[1] Cyrany J, Rejchrt S, Kopacova M et al. Buried bumper syndrome: a complication of percutaneous endoscopic gastrostomy. World J Gastroenterol 2016; 22: 618-627

[2] Klein S, Heare BR, Soloway RD. The "buried bumper syndrome": a complication of percutaneous endoscopic gastrostomy. Am J Gastroenterol 1990; 85: 448-451

[3] Mueller-Gerbes D, Hartmann B, Lima JP et al. Comparison of removal techniques in the management of buried bumper syndrome: a retrospective cohort study of 82 patients. Endosc Int Open 2017; 5: E603-E607

[4] Hindryckx P, Dhooghe B, Wannhoff A. A novel device for the endoscopic management of buried bumper syndrome. Endoscopy 2019; 51: 689-693

[5] Curcio G, Granata A, Ligresti D et al. Buried bumper syndrome treated with HybridKnife endoscopic submucosal dissection. Gastrointest Endosc 2014; 80: 916-917 